\title{
COMPARATIVE STUDY OF EFFICACY OF AMOXICILLIN WITH ORNIDAZOLE AND OFLOXACIN WITH ORNIDAZOLE IN PATIENTS WITH DENTAL CARIES
}

\author{
Sakthivel K*, Annapoorani S, Senthamarai R \& Rajesh C \\ Periyar College of Pharmaceutical Sciences, Tiruchirappalli-620 021 Tamil Nadu, India \\ *For correspondence: \\ Mr. K. Sakthivel \\ Head, Department of Pharmacy Practice \\ Periyar College of Pharmaceutical Sciences \\ Tiruchirappalli-620021, Tamil Nadu - India. \\ Mobile: 09894193707 \\ Email: < sakthipractice@gmail.com >
}

\begin{abstract}
Dental caries is one of the most common preventable diseases which recognized as the primary cause of oral pain and tooth loss. It is a major public health oral disease which hinders the achievement and maintenance of oral health in all age groups. WHO claimed that poor oral health may have a profound effect on general health as well as quality of life, and several oral diseases are related to chronic diseases. To compare the Efficacy of Amoxicillin with Ornidazole and Ofloxacin with Ornidazole in the treatment of Dental caries and to determine the Minimal Inhibitory Concentrations to reduce the toxicity. The study was carried out in an outpatient department of a Dental Hospital located at Tiruchirappalli, Tamilnadu, India. The selected 50 patients, 25 patients were in Group A (Amoxicillin 500mg with Ornidazole 500mg) and the remaining 25 patients were in Group B (Ofloxacin 200mg with Ornidazole $750 \mathrm{mg}$ ) The combination drug Ofloxacin - Ornidazole is very effective and safe in the management of dental caries caused by various microorganisms about $47 \%$ of the patients who were in Amoxicillin - Ornidazole were very satisfied whereas $63 \%$ of the patients who were in Ofloxacin - Ornidazole were extremely satisfied with the treatment.
\end{abstract}

Key Words: Dental caries, Efficacy, Amoxicillin, Ofloxacin, Ornidazole 


\section{INTRODUCTION}

Dental caries is one of the most common preventable diseases which is recognized as the primary cause of oral pain and tooth loss. It is a major public health oral disease which hinders the achievement and maintenance of oral health in all age groups ${ }^{\mathbf{1}}$. WHO pointed that the global problem of oral disease still persists despite great improvements in the oral health of population in several countries. WHO claimed that poor oral health may have a profound effect on general health as well as quality of life, and several oral diseases are related to chronic diseases ${ }^{2}$.

Dental caries refers to the localized destruction of susceptible dental hard tissues by acidic by-products from the bacterial fermentation of dietary carbohydrates. It is a chronic disease that progresses slowly in most of the people ${ }^{3}$ which results from an ecological imbalance in the equilibrium between tooth minerals and oral biofilms (plaque) ${ }^{4}$.

\section{CLASSIFICATION OF DENTAL CARRIES ${ }^{5}$}

Classification of dental carries as per the symptoms is as follows.

Class I - Buccal or lingual pits on molars, Occlusal surfaces of posterior teeth, lingual pit near cingulum of maxillary incisors.

Class II - proximal surfaces of posterior teeth.

Class III - Interproximal surfaces of anterior teeth without incisal edge involvement.

Class IV - Interproximal surfaces of anterior teeth with incisal edge involvement. Class V Cervical third of facial or lingual surface of tooth.

Class VI - Incisal or occlusal edge worn away due to abrasion.

\section{Table - 2. Classification by rate of progression, affected hard tissues and loation ${ }^{6}$}

\begin{tabular}{|l|l|l|}
\hline On the basis of & Classification & Description \\
\hline Rate of progression & Acute & $\begin{array}{l}\text { Signifies a quickly developing } \\
\text { condition }\end{array}$ \\
\cline { 2 - 3 } & Chronic & $\begin{array}{l}\text { Signifies an extended time to } \\
\text { developing condition }\end{array}$ \\
\hline Affected hard tissue & Enamel & $\begin{array}{l}\text { Early in its development and may } \\
\text { affect only enamel }\end{array}$ \\
\cline { 2 - 3 } & Dentinal & $\begin{array}{l}\text { The extent of decay reaches the } \\
\text { deeper layer of dentin }\end{array}$ \\
\cline { 2 - 3 } & Cementum & The decay on roots of teeth \\
\hline Location & Class I & $\begin{array}{l}\text { Pit and fissure caries (anterior or } \\
\text { posterior teeth) }\end{array}$ \\
\cline { 2 - 3 } & Class II & $\begin{array}{l}\text { Approximal surfaces of posterior } \\
\text { teeth }\end{array}$ \\
\hline
\end{tabular}




\begin{tabular}{|l|l|}
\hline Class III & $\begin{array}{l}\text { Approximal surfaces of anterior } \\
\text { teeth without incisal edge } \\
\text { involvement }\end{array}$ \\
\hline Class IV & $\begin{array}{l}\text { Approximal surfaces of } \\
\text { anterior } \\
\text { teeth with incisal edge } \\
\text { involvement }\end{array}$ \\
\hline Class V & $\begin{array}{l}\text { Gingival/cervical surfaces on the } \\
\text { lingual or facial aspect (anterior or } \\
\text { posterior) }\end{array}$ \\
\hline Class VI & $\begin{array}{l}\text { Incisal edge of anterior teeth or } \\
\text { cusp heights of posterior teeth }\end{array}$ \\
\hline
\end{tabular}

\section{DIAGNOSIS OF DENTAL CARIES}

\section{Primary diagnosis}

Initially it may appear as a small chalky area (smooth surface caries) which may eventually develop into a large cavitation. Inspection of all visible tooth surfaces using a good light source, dental mirror and explorer. Dental radiographs (X-rays) are used for less visible areas of teeth in particular caries between the teeth.

\section{Disease indicator}

Caries disease indicators are explained as physical signs of the presence of current dental caries disease or past dental caries disease history and activity. These indicators act as strong predictors of caries continuing unless implementation of the therapeutic intervention is made.

The four disease indicators:

Visible white spots on smooth surfaces

Last 3 years restorations placed in the oral cavity as a result of caries

Lesions approximating enamel visible on dental radiographs

Carious cavitation lesions are showing radiographic penetration into the dentin.

\section{Risk Factor}

Absence of saliva, meaning hyposalivation or salivary hypofunction

Habits such as frequent ingestion of fermentable carbohydrates, and poor oral hygiene.

Habits such as frequent ingestion of fermentable carbohydrates, and poor oral hygiene

\section{Differential diagnosis}

Dental fluorosis and developmental defects of the tooth including hypo mineralization of the tooth and hypoplasia of the tooth are used for dental caries ${ }^{7}$. 


\begin{abstract}
Aim:
The aim of this study is to the Compare efficacy of Amoxicillin with Ornidazole and Ofloxacin with Ornidazole in patients with dental caries
\end{abstract}

\title{
Objective:
}

To evaluate and compare the efficacy of Amoxicillin with Ornidazole and Ofloxacin with Ornidazole.

To determine the Minimal Inhibitory Concentrations to reduce the toxicity.

\section{MATERIALS AND METHODS}

\section{Site of the study}

The study on "Compare efficacy of Amoxicillin with Ornidazole and Ofloxacin with Ornidazole in patients with dental caries" was carried out in Dental Hospital located at Tiruchirappalli, from December 2019.

\section{Department selected for study in the hospital}

Patients selected for the study were outpatient of Dental department.

\section{Consent from the Hospital Authority}

It is customary that every project work carried out in the clinical wards of the hospital by the Department of Pharmacy Practice is informed to all the Physicians, Surgeons and other Healthcare professionals of the hospitals after the approval from Ethics committee. Henceforth, a protocol of the study, which includes the objectives, methodology, etc., was submitted to the Managing Director of the hospital. The scholar was permitted to utilize the hospital facilities and to make follow up in the selected departments. Patients were selected as per selection criteria and their consents were obtained.

\section{Study design}

\section{Design of data entry format (Proforma)}

A separate data entry format (Proforma) for incorporating patient details are designed.

The format will contain details such Name, Age, Diagnosis, Past medical history, etc.

\section{Proforma - I:}

Patient informed consent form

\section{Proforma - II:}

Patient details - Name, Age, Sex, Address, Occupation, Social History, Diagnosis, Pantry, Past Medical History, Treatment mode etc are incorporated.

\section{Patient inclusion criteria}

1. Gender both Male and Female

2. Age from 18 to 60

3. Patients who are willing to give consent 


\section{Patient exclusion criteria}

1. Not above the age of 60

2. Patients with co-morbid

3. Pregnancy and lactative women's

\section{Methodology}

- About 50 patients are selected based on the inclusion and exclusion criteria placed in 2groups.

- Group A includes 25 patients receiving Amoxicillin 500mg with Ornidazole 500mg thrice a day

- Group B includes 25 patients receiving Ofloxacin200mg with Ornidazole $750 \mathrm{mg}$ twice a day

\section{Minimal Inhibitory Concentration}

The antibiotic which is effective against the microorganism isolated from the collected sample were undergo serial dilution in a broth. An equal amount of bacterial suspension of the test organism was added to each tube. Following overnight incubation $37^{\circ} \mathrm{C}$ turbidity of each tube was noticed. Highest dilution of the antibiotic was determined in which there was no growth of the organism or the nutrient broth was clear (no turbidity).

The broth micro dilution assay method was used to determine the MICS for the

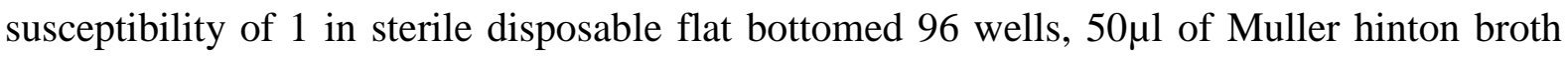
and $25 \mu \mathrm{l}$ of the varying concentrations of the test sample (Of + Or) was added in decreasing order $64 \mu 1$ to $0.25 \mu 1$ along with $25 \mu 1$ of the test organism suspension. For positive control 50 $\mu 1$ of the broth and $50 \mu 1$ of Ciprofloxacin and $25 \mu 1$ of the test organism were added. The plates were then incubated at $37^{\circ} \mathrm{C}$ for $18-24$ hours. The results were noted by observing the turbidity. Changes of the colour was observed and recorded. The highest dilution that shows no growth is minimum inhibitory concentration ${ }^{8}$.

\section{Statistical analysis}

The values obtained will be subjected to statistical analysis by one way ANOVA

\section{RESULT AND DISCUSSION}

\section{Demographic Age:}

In Group A, 8 patients (32\%) was in the age group of $21-30$ years, 3 patients (12\%) were in the age group of 31- 40 years, 5 patients $(20 \%)$ were in the age group of $41-50$ years \& 9 patients $(36 \%)$ were in the age group of $51-60$ years. In Group B, 0 patients were in the age group of $21-30$ years, 9 patients $(36 \%)$ were in the age group of $41-50$ years, 6 patients $(24 \%)$ were in the age group of $51-60$ years. 10 patients $(40 \%)$ were in the group of 51- 60 years.

. The demographic data of both Group A and Group B indicates that more number of patients was in the age group of $51-60$ years. 


\section{Gender:}

Among the demographic data collected in Group A, 12patients (48\%) were males and 13 patients $(52 \%)$ were females. In Group B, 11 patients (44\%) were males \& 14 patients $(56 \%)$ were females.

\section{Diet habits:}

In Group A, 5 patients (20\%) were vegetarian and 20 patients $(80 \%)$ are on mixed diet. In case of Group, B 6 patients (24\%) are vegetarian \& 19 patients (76\%) are on mixed diet.

\section{Chronicity of disease:}

In Group A, 3 patients (12\%) are in $0-5$ years of disease chronicity, 10 patients $(40 \%)$ are in $6-10$ years and 12 patients (48\%) are in 11- 15 years of disease chronicity. In Group B, 2 patients (8\%) are in $0-5$ years of diseases chronicity, 9 patients $(36 \%)$ of the patients are in $6-10$ years and 14 patients $(56 \%)$ are in $11-15$ years of disease chronicity.

\section{Social habits:}

In Group A, 5 patients (20\%) were smokers, 6 patients (24\%) Were both smoker and alcoholic, 13 patients (52\%) were tea totaler, 1 patient was (4\%) using betelnut. In Group B, 5 patients $(20 \%)$ were smokers, 5 patients $(20 \%)$ were both smoker and alcoholic, 13 patients $(52 \%)$ were tea totaler, and 2 patients $(8 \%)$ were using betelnut.

\section{ANTI MICROBIAL ACTIVITY}

The Table $01 \& 02$ Shows the zone of inhibition of the test drug against test organism Streptococcus mutans, Streptococcus mitis, Streptococcus sanguis, Streptococcus salivarius which are collected from the 50 patients. 
TABLE -01

ANTIMICROBIAL STUDY

GROUP A

\begin{tabular}{|c|c|c|c|c|c|}
\hline \multirow[t]{2}{*}{$\begin{array}{l}\text { Sample } \\
\text { Number }\end{array}$} & \multirow[t]{2}{*}{ Name of the Organism } & \multicolumn{4}{|c|}{ Zone of Inhibition In mm } \\
\hline & & Amoxicillin & Ornidazole & $\begin{array}{l}\text { Amoxicillin } \\
\text { \&Ornidazole }\end{array}$ & Standard \\
\hline A1. & S. mutans & 14 & 15 & 18 & 21 \\
\hline A 2. & S. sanguis & 12 & 12 & 15 & 17 \\
\hline A3. & S. mutans & 15 & 15 & 20 & 21 \\
\hline A4. & S. mutans & 10 & 14 & 17 & 20 \\
\hline A5. & S. mutans & 12 & 14 & 18 & 19 \\
\hline A6. & S. mitis & 13 & 14 & 15 & 18 \\
\hline A7. & S. mutans & 12 & 14 & 20 & 21 \\
\hline A8. & S. mutans & 12 & 15 & 19 & 20 \\
\hline A9. & S. sanguis & 10 & 12 & 14 & 16 \\
\hline A10. & S. mutans & 14 & 12 & 18 & 19 \\
\hline A11. & S. sanguis & 10 & 13 & 15 & 17 \\
\hline A12. & S. mutans & 15 & 16 & 20 & 21 \\
\hline A13. & S. mutans & 16 & 18 & 20 & 19 \\
\hline A14. & S. mitis & 11 & 14 & 14 & 16 \\
\hline A15. & S.mutans & 12 & 15 & 20 & 22 \\
\hline A16. & S. mutans & 9 & 12 & 19 & 20 \\
\hline A17. & S.mutans & 12 & 14 & 16 & 21 \\
\hline A18. & S. sanguis & 12 & 13 & 13 & 15 \\
\hline A19. & S. mitis & 11 & 12 & 14 & 17 \\
\hline A20. & S. mutans & 10 & 14 & 18 & 21 \\
\hline A21. & S. salivarius & 11 & 12 & 13 & 15 \\
\hline A22. & S. mitis & 10 & 12 & 14 & 13 \\
\hline A23. & S. mutans & 12 & 14 & 20 & 21 \\
\hline A24. & S. mutans & 10 & 12 & 16 & 17 \\
\hline A25. & S. mitis & 10 & 12 & 14 & 15 \\
\hline & $\mathrm{MEAN} \pm \mathrm{SD}$ & $11.8 \pm 1.811$ & $13.6 \pm 1.523$ & $16.8 \pm 2.497$ & $18.48 \pm 2.467$ \\
\hline
\end{tabular}


TABLE - 02

ANTIMICROBIAL STUDY

GROUP B

\begin{tabular}{|c|c|c|c|c|c|}
\hline \multirow{2}{*}{$\begin{array}{l}\text { Sample } \\
\text { Number }\end{array}$} & \multirow[t]{2}{*}{ me of the Organism } & \multicolumn{4}{|c|}{ Zone of Inhibition In mm } \\
\hline & & Ofloxacin & Ornidazole & $\begin{array}{l}\text { Ofloxacin \& } \\
\text { Ornidazole }\end{array}$ & Standard \\
\hline B1. & S. mitis & 25 & 15 & 28 & 21 \\
\hline B2. & S. mutans & 26 & 15 & 30 & 22 \\
\hline B3. & S. mutans & 25 & 14 & 28 & 21 \\
\hline B4. & S. sanguis & 25 & 15 & 28 & 21 \\
\hline B5. & S. mutans & 28 & 15 & 32 & 21 \\
\hline B6. & S. mutans & 25 & 13 & 29 & 21 \\
\hline B7. & S. mutans & 30 & 14 & 34 & 22 \\
\hline B8. & S. mitis & 28 & 15 & 30 & 22 \\
\hline B9. & S. mutans & 25 & 15 & 32 & 23 \\
\hline B10. & S. mutans & 28 & 13 & 30 & 20 \\
\hline B11. & S. salivarius & 27 & 14 & 31 & 21 \\
\hline B12. & S. mutans & 26 & 14 & 30 & 21 \\
\hline B13. & S. mutans & 29 & 15 & 34 & 22 \\
\hline B14. & S. mutans & 30 & 15 & 35 & 22 \\
\hline B15. & S. sanguis & 30 & 15 & 32 & 22 \\
\hline B16. & S. mutans & 28 & 12 & 32 & 21 \\
\hline B17. & S. mutans & 26 & 12 & 28 & 20 \\
\hline B18. & S. mutans & 27 & 14 & 31 & 22 \\
\hline B19. & S. salivarius & 30 & 15 & 33 & 22 \\
\hline B20. & S. mutans & 31 & 15 & 34 & 21 \\
\hline B21. & S. mutans & 28 & 12 & 30 & 20 \\
\hline B22. & S. salivarius & 29 & 15 & 30 & 21 \\
\hline B23. & S. mutans & 30 & 15 & 32 & 22 \\
\hline B24. & S. mutans & 30 & 15 & 35 & 22 \\
\hline B25. & S. mutans & 28 & 13 & 31 & 20 \\
\hline & Mean \pm SD & $27.76 \pm 1.924$ & $14.2 \pm 1.058$ & $31.16 \pm 2.129$ & $21.32 \pm 0.785$ \\
\hline
\end{tabular}




\section{Minimal Inhibitory Concentration}

Table 03 shows Minimal inhibitory concentration of Group B which are more sensitive in the above zone of inhibition study.

TABLE - 03

\begin{tabular}{|l|c|c|c|c|}
\hline Dilution Factor & S. mutans & S. mitis & S. sanguis & S. salivarius \\
\hline $16(64 \mu \mathrm{g})$ & $\mathrm{T}$ & $\mathrm{T}$ & $\mathrm{T}$ & $\mathrm{T}$ \\
\hline $8(32 \mu \mathrm{g})$ & $\mathrm{T}$ & $\mathrm{T}$ & $\mathrm{T}$ & $\mathrm{T}$ \\
\hline $4(16 \mu \mathrm{g})$ & $\mathrm{T}$ & $\mathrm{T}$ & $\mathrm{T}$ & $\mathrm{T}$ \\
\hline $2(8 \mu \mathrm{g})$ & $\mathrm{T}$ & $\mathrm{T}$ & $\mathrm{T}$ & $\mathrm{T}$ \\
\hline $1(4 \mu \mathrm{g})$ & $\mathrm{T}$ & $\mathrm{T}$ & $\mathrm{T}$ & $\mathrm{T}$ \\
\hline $0.5(2 \mu \mathrm{g})$ & $\mathrm{MIC}$ & $\mathrm{MIC}$ & $\mathrm{MIC}$ & $\mathrm{MIC}$ \\
\hline $0.25(1 \mu \mathrm{g})$ & $\mathrm{NG}$ & $\mathrm{NG}$ & $\mathrm{NG}$ & $\mathrm{NG}$ \\
\hline Positive Control & $\mathrm{NG}$ & $\mathrm{NG}$ & $\mathrm{NG}$ & $\mathrm{NG}$ \\
\hline Negative Control & $\mathrm{NG}$ & $\mathrm{NG}$ & $\mathrm{NG}$ & NG \\
\hline
\end{tabular}

T - Turbidity

NG - No Growth

MIC - Minimal Inhibitory Concentration

\section{CONCLUSION}

This study was designed to compare the drugs Amoxicillin/Ornidazole with Ofloxacin/Ornidazole in patients with dental caries. Based on the inclusion and exclusion criteria 50 dental caries patients were selected for the study. From this selected 50 patients, 25 patients were treated with Amoxicillin/Ornidazole (Group A), 25 patients were treated with Ofloxacin /Ornidazole (Group B).

Out of the selected 50 patients 8 patients were in the age group of 21-30 years, 12 patients (24\%) were in the age group of 31-40 years, 11 patients (22\%) were in the age group of 41 50 years, 19 patients (38\%) were in the age group of $51-60$ years. It clearly indicates that the older age is highly affected by means of dental caries.

Out of 50 patients, 23 patients (46\%) were male and the remaining 27 patients (54\%) were female which confirms that female are more likely to have dental caries than men.

The samples collected from the dental caries were subjected to colony characterization and biochemical test. From this four different microorganism were identified such as 
Streptococcus mutans, Streptococcus salivarius, Streptococcus mitis, Streptococcus sanguis. Out of the selected 50 patients, 33 patients (66\%) carrying S. mutans, 7 patients(14\%) carrying S. mitis, 5 patients (10\%) samples carrying S. sanguis, 5 patients (10\%) samples carrying $S$. salivarius.

$>$ These samples were undergoes for the antimicrobial study for the test drug Amoxicillin with Ornidazole, Ofloxacin with Ornidazole combination. According to the measured value of zone of inhibition Ofloxacin with Ornidazole combination had the better antimicrobial activity.

This combination (Ofloxacin with Ornidazole) which is more effective is further studied for MIC.

$>$ MIC was calculated based on the turbidity produced in well. From the Minimum Inhibitory Concentration produced in the concentration $0.5 \mu \mathrm{g}$ for $S$. mutans \& S. mitis and $1 \mu \mathrm{g}$ for $\quad S$. sanguis, S. salivarius.

The combination drug Ofloxacin - Ornidazole is very effective and safe in the management of dental caries caused by various microorganisms.

\section{BIBLIOGRAPHY}

1. Thean $\boldsymbol{H}$, Wong $\mathbf{M L}$ and Koh $\boldsymbol{H}$. The dental awareness of nursing home staff in Singapur- a pilot study. Gerodontology. 2007; 24: 58-63.

2. Petersen PE, Bourgeois D, Ogwa H. Estupinan-Day S, and Ndiaye C. The global burden of disease and risks to oral health. Bull world health organ. 2005; 83: 661- 669.

3. Selwitz RH, Ismail AI and Pitts NB. Dental caries. Lancet. 2005; 369: 51-59.

4. Nyvad B and Takahashi $N$. Caries ecology revisited: microbial dynamics and the caries process. Caries Res. 2008; 42: 409- 418.

5. DYE, B. (2010). Trends in Oral Health by Poverty Status as Measured by Healthy People 2010 Objectives. Public Health Reports, 125(6), 817

6. Sonis ST. Dental Secrets. 3rd edition. Philadelphia. 2003; pp 130.

7. Mohsen Kazeminia, Alireza Abdi Dental caries in primary and permanent teeth in children's worldwide, 1995 to 2019 www.rxlist.com

8. Chowdaiah M, Santosh Kumar, Dhamodhar P. An overview on the prevalence of drug resistant Streptococcus mutans in dental caries patients. 2016. 15-18. 